\title{
Differential susceptibility to hypoxia aids estuarine invasion
}

\author{
James E. Byers* \\ Department of Ecology, Evolution, and Marine Biology, University of California, Santa Barbara, California 93106, USA
}

\begin{abstract}
I examined the resistance of 2 competing estuarine mudsnails, Cerithidea californica (native) and Batillaria attramentaria (exotic), to mortality from microbes and associated alteration of the abiotic environment (i.e., hypoxia). B. attramentaria is displacing C. californica from salt marshes of northern California where the 2 species overlap. I first examined the mortality and distribution of the snails during 2 natural experiments in Bolinas salt marsh (Marin Co., California, USA) that exposed the snails to high bacteria levels and low oxygen conditions for prolonged periods ( $>3 \mathrm{wk}$ ). Second, I conducted 2 laboratory experiments designed to quantify the rates and mechanisms of snail mortality related to bacterial activity. In both the field and the lab, B. attramentaria was significantly more resistant to death by low oxygen. Lab experiments demonstrated that indirect effects of bacteria, i.e., low oxygen levels (as opposed to direct infection by bacteria), were responsible for the high mortality rate of $C$. californica. In the field, $C$. californica seemed able to mitigate effects of hypoxia by migrating away from sources of high stress, but only when the harmful bacterial activity was highly localized. Ultimately this study illustrates that stress from microbial action differentially affects the 2 competing species and thus contributes to the invader's documented displacement of the native in marshes where they co-occur. Given the growing incidence of eutrophication and associated anoxic conditions in near-shore aquatic environments worldwide, differential susceptibility to hypoxia/anoxia may increasingly contribute to the outcomes of biological invasions in these habitats.
\end{abstract}

KEY WORDS: Dissolved oxygen depletion · Non-indigenous species $\cdot$ Introduced species $\cdot$ Exotic species · Anoxia · Batillaria attramentaria $\cdot$ Cerithidea californica $\cdot$ Hydrogen sulfide $\cdot$ Salt marshes

\section{INTRODUCTION}

As invasions of exotic species in aquatic ecosystems increase (Drake et al. 1989, Carlton 1992, Carlton \& Geller 1993, Lodge 1993, Mills et al. 1993, Lafferty \& Kuris 1996, Cohen \& Carlton 1998), evaluation of the mechanisms contributing to invaders' success becomes increasingly important. Escape from natural enemies is frequently identified as an advantage contributing to the proliferation of non-indigenous species (Huffaker 1971, Lawton \& Brown 1986, Crawley 1987, Wilson

\footnotetext{
${ }^{*}$ Present address: Friday Harbor Marine Laboratories, University of Washington, 620 University Road, Friday Harbor, Washington 98250, USA. E-mail: jbyers@u.washington.edu
}

1989, Wells \& Henderson 1993, Trowbridge 1995). However, the emphasis in the 'freedom from natural enemies' paradigm has been on macropredators. The influence of microscopic natural enemies, e.g., bacteria or parasites, on invasion failure or success is almost always overlooked despite these organisms' ubiquity and often extreme influence on species' life histories, distributions, and population dynamics (Price et al. 1986, Hochberg 1991, Sikorowski \& Lawrence 1994). For a fuller understanding of invasion mechanisms we must incorporate evaluation of these 'unseen' players into analyses of invasion success (Settle \& Wilson 1990, Barber \& Mann 1994, Hanley et al. 1995, Chu 1996, Byers 2000a).

Similar to macropredators, microscopic enemies could theoretically help to either prevent or promote 
biological invasion. But unlike typical predators or parasites, microscopic enemies can commonly exert indirect species. These indirect effects occur when microbes alter the abiotic conditions in the surrounding environment. For example, bacteria rapidly consume oxygen (e.g., Porter et al. 1996, Uncles et al. 1998) and produce toxic extracellular products, e.g., $\mathrm{H}_{2} \mathrm{~S}$ (Landsberg 1995, Gunnlaugsdottir \& Gudmundsdottir 1997). Such alteration of the physical environment, which is usually accentuated by certain hydrographic conditions (e.g., Breitberg 1990, Lenihan \& Peterson 1998), can impact species differentially, frequently by imposing differential mortality (Das \& Stickle 1993, Marcus \& Lutz 1994, Vistisen \& Vismann 1997). In the case of successful invasion, heightened resistance to byproducts or environmental conditions created by microbial activity (e.g., hypoxia, $\mathrm{H}_{2} \mathrm{~S}$ ) may play a role in allowing the exotic species to experience lower mortality rates than native analogues. If the native and exotic species compete, differential susceptibility may accentuate competitive outcomes by helping to reduce the numbers, fitness, or competitive abilities of the native competitor (Park 1948, Freeland 1983, Price et al. 1988, Minchella \& Scott 1991, Schall 1992), leading to declines or exclusion of the native species. As low oxygen events, such as hypoxia $(<2 \mathrm{mg}$ $\mathrm{O}_{2} \mathrm{l}^{-1}$ ) and anoxia $\left(0 \mathrm{mg} \mathrm{O}_{2} \mathrm{l}^{-1}\right)$, increase globally in frequency and duration in near-shore and estuarine environments (Officer et al. 1984, Elmgren 1989, Cooper \& Brush 1991, Parker \& O'Reilly 1991, Dyer \& Orth 1995, Iversen et al. 1998), exposing the influence of this mechanism on invasion success is essential. Here I initiate exploration of the potential for oxygen depletion events to influence the outcomes of the increasing number of biological invasions.

The interaction between the 2 salt marsh mudsnails Cerithidea californica and Batillaria attramentaria is well suited to address the role of microbial activity in invasion success. The common horn snail C. californica is an abundant epifaunal grazer in marshes from San Ignacio Bay, Mexico to Tomales Bay, California, USA. The exotic mudsnail B. attramentaria was introduced to the West Coast of North America in the late 1920s with aquaculture imports of the Pacific oyster Crassostrea gigas (Bonnot 1935, Barrett 1963). Because it produces eggs that attach to the mud surface and develop directly (Whitlatch 1974, Yamada \& Sankurathri 1977), B. attramentaria has stayed confined within the bays to which it was introduced. In bays in northern California the native snail has declined and, in a few areas where $B$. attramentaria has attained high abundances, C. californica may have disappeared entirely (Carlton 1975, McDermott 1996, Byers 1999). Both species compete for epipelic diatoms on the marsh surface and B. attramentaria's superior resource conversion efficiency has been demonstrated as a sufficient mechanism to account for the displacement of C. californica (Byers 2000a). Also, the snails harbor several species of trophically transmitted trematode parasites (Sousa 1983, Lafferty 1993, McDermott 1996), which castrate the snails at even low levels of infection, and appear to aid $B$. attramentaria by infecting $C$. californica at a higher frequency (McDermott 1996, Byers 2000a).

In addition to the documented differences between the species that contribute to Batillaria attramentaria's invasion, susceptibility to microbial activity may also influence the outcome of the invasion. I first noticed the potential for bacteria to play a role in the dynamics of the snails' populations after observing the effect of submersion on snails that I was maintaining in an aquarium. After several months, despite a mud substrate with food (epipelic diatoms) and constant aeration, the snails died and a white growth appeared on the shells of some. Also, in late spring of 1996 after the mouth of Carpinteria salt marsh (Santa Barbara Co., California) was closed for 4 to $5 \mathrm{~d}$ due to severe sedimentation, I noticed many sluggish and several dead Cerithidea californica with bacteria on the shells, even 2 to $3 \mathrm{~d}$ after the marsh's channel was re-opened. In both cases, it was not known whether the bacteria found on dead snails were the direct agents of mortality or an opportunistic scavenger on dead material. Here I report on 2 natural experiments involving bacterial exposure that arose in Bolinas salt marsh (Marin Co., California) as well as the results of 2 laboratory experiments designed to determine more precisely the role of microbes in aiding the proliferation of $B$. attramentaria and displacement of $C$. californica in marshes of northern California. The goals of this study are to determine (1) if microbial activity influences the invasion process by causing differential mortality in the competing snail species, and (2) if snail mortality is due to direct, pathogenic effects of bacteria or to more indirect, density-independent effects on snails caused by alteration of the surrounding environment by bacterial activity.

\section{METHODS}

Natural experiments. The first natural experiment in Bolinas Lagoon (Marin Co., California) was the $\sim 3 \mathrm{wk}$ submersion of an area within the salt marsh containing sympatric snail populations. Bolinas Lagoon is a unique site because it contains the only marsh on the West Coast of North America where both species currently reside in relatively equal densities (Byers 1999). I had been measuring densities of Cerithidea californica and Batillaria attramentaria in 4 sympatric populations in the southern marsh of Bolinas since 1994 as 
part of a long-term monitoring study to examine the rate of native species displacement by the exotic Batillaria. The populations that I monitored resided in 4 distinct marsh pannes, elevated and isolated areas of exposed mud surrounded by vegetation. Because of the relatively stationary early life histories of these snail species (Whitlatch 1974, Yamada \& Sankurathri 1977) and typically limited movement as adults (J.E.B. unpubl. data), marsh pannes contain essentially closed populations. Density measurements of each species, live and dead, were counted in all years with a $0.05 \mathrm{~m}^{2}$ quadrat that was placed haphazardly inside each marsh panne. The number of quadrats used varied ( $n=5$ to 12) depending on the size of the panne. In the summer of 1996, I added another, smaller marsh panne $\left(8 \mathrm{~m}^{2}\right)$ to the sampling design. During the early summer of 1998 this panne became blocked off with sediment and debris and did not drain or flush for $>3 \mathrm{wk}$. Consequently, the water in the panne (depth $\sim 0.3 \mathrm{~m}$ ) became stagnant and the opportunity arose to examine the effects of prolonged submersion on mortality of the 2 competitors.

First, I used a 1-way ANOVA (with time as the factor, and each year from 1996 to 1998 as levels) and posthoc Tukey tests to determine significant differences in the population densities of the 2 snail species between years in this submerged panne. Due to heteroscedasticity in Cerithidea californica data, I log-transformed data $\left[x^{\prime}=\ln (x+1)\right]$ for both species. Sample sizes were too small to test for normality; however, there was no skewness or kurtosis to the distributions of transformed density counts. Second, I compared the relative change in density for each species during years both before and after the submersion event. Specifically, I compared the slope of the log of density between 1996 and 1997, i.e., before the submersion event, using a $t$-test that compared the single change measured in the submerged panne with the average decrease in the control marsh pannes (Sokal \& Rohlf 1995). Similarly, I performed this same comparison on the change in density for the period 1997 to 1998, i.e., encompassing the submersion event, to determine if the population trends of each species in the submerged panne were significantly different from those of the control areas.

A second natural experiment presented itself in the summer of 1998 to test the snails' relative tolerance to bacteria and associated anoxic conditions. A deer, presumably hit by a car on the road only $50 \mathrm{~m}$ to the west of the marsh, died in a panne; however, not one that was currently monitored for snail densities. The carcass was first noted already partially decomposed on July 2, 1998, with a pool of standing water a few cm deep around it. The sediment in the immediate vicinity was black and highly anoxic, and pink and white bac- terial rings emanated out to a distance of $0.4 \mathrm{~m}$ from the deer. On September 2, 1998, I sampled snail densities in this panne in 2 concentric rings around the carcass, still delineated by bacterial film, using a $0.05 \mathrm{~m}^{2}$ quadrat. The first concentric ring included the deer and the area within a $0.4 \mathrm{~m}$ radius of the deer. This distance incorporated all of the bacterial film and anoxic mud visible on the surface. The outer concentric ring extended another $1.0 \mathrm{~m}$ from the outer edge of the inner ring and contained the rest of the panne. Finally, a small, shallow, muddy channel that fed the panne on the landward side, $1.5 \mathrm{~m}$ from the deer, was also censused. Because this corridor channeled water into and out of the panne, I assumed it would experience greater flushing, and thus less concentrated exposure to the bacteria and anoxic conditions associated with the carcass. Four replicate quadrats were counted in each of the 3 areas. Differences in Batillaria attramentaria density between these 3 sample areas were compared via 1-way ANOVA with sampling area as the factor to determine if the snails' density varied as a function of proximity to this large bacterial source. Data were not transformed for this analysis because the variances of the means were homoscedastic. Because no live Cerithidea californica were found in the inner sampling circle, C. californica density was compared only between the outer ring and the channel with a Student's t-test. In July 1999 I resampled this panne in identical fashion. Again, ANOVA was used to compare the density of each species as a function of location within the panne.

Laboratory experiments. I conducted 2 laboratory experiments to complement these natural field experiments. To experimentally quantify mortality rates of each species due to continued submersion in stagnant water, in May 1996 I collected both species from Bolinas Lagoon. To test for potential differences in resistance to low dissolved oxygen levels by snails from different sites within the marsh, 3 different sympatric populations (i.e., marsh pannes) within Bolinas Lagoon were used as sources. I picked snails out of the mud by hand and skimmed the top $2 \mathrm{~cm}$ of mud with a trowel, which I carefully laid inside individualized compartments (area $\sim 15 \mathrm{~cm}^{2}, 4 \mathrm{~cm}$ deep) of partitioned plastic boxes (either 6, 9 or 24 compartments each) so that the mud surface stayed face up. In a covered, open-air shed I randomly immersed a total of 55 of these partitioned boxes in 2 seawater tray tables, to keep temperature constant between boxes. I allowed the snail boxes to sit overnight with ambient flow-through seawater $\left(15^{\circ} \mathrm{C}\right)$. The next day (May 14$)$ I placed a single snail (>15 mm) into each individualized, water-filled compartment of the partitioned boxes, putting each snail from a given collection site onto mud from the same site. With 1 snail per $15 \mathrm{~cm}^{2}$, the density inside a 
compartment was equivalent to intermediate field densities of each species (Byers 1999); thus diatoms growing on the mud surface should not have been limiting. I attached the lids of the partitioned boxes to prevent snails from exiting their individual compartments and to limit water loss due to evaporation. Every $3 \mathrm{~d}$ I opened the lids of the containers to examine the snails. Because these intertidal snails do not normally experience submersion in water of this low temperature for extended periods in the marsh, to mimic field conditions I heated the water in each tray table with 2 aquarium heaters. The temperature stabilized after $2 \mathrm{~d}$ at $\sim 19.5^{\circ} \mathrm{C}$. On June 6 (after 23 elapsed days) I removed all dead snails. Dead snails did not respond to prodding of the tissue, smelled pungent, usually had black stained shells, and often had white bacterial films in their apertures. If a snail was not obviously dead according to these criteria, I cracked it open to look at its tissue. On June 11 (28 elapsed days) I pulled out additional snails which had since died. Dead snails were recorded according to species and to the area from which they had been collected in the marsh.

To determine the effect of species and collection area on the death rate from submersion (after Day 28), I analyzed the data with a 3-dimensional $(2 \times 2 \times 3)$ chisquared analysis to test for independence between mortality, species and collection location (Zar 1996). Additionally, I pooled data for each species over all collection sites to test for differences between species in infection with a chi-squared $(2 \times 2)$ analysis. To prevent erroneous inflation of the $\chi^{2}$ value in this analysis and other chi-squared tests where $\mathrm{df}=1$, I applied Yates correction for continuity (Zar 1996). Finally, I examined Cerithidea californica alone (since only $C$. californica was substantially affected by submersion) for microhabitat differences in the mortality rate of snails from the 3 collection sites, using chi-squared analysis. I also analyzed C. californica's mortality between pairs of collection sites via $2 \times 2$ chi-squared tests. If 2 sites were found to be homogeneous, I pooled them for further pairwise tests against the remaining site.

I undertook a second lab experiment on April 9, 1999, to ascertain the role of bacteria in Cerithidea californica mortality and to examine the specific mechanism by which microbes exacted their effect. Because Batillaria attramentaria clearly exhibited little mortality in the field and lab under stagnant conditions, only C. californica was used in this study. Since bacteria in both the field and the lab were observed on almost all dead snails, I wanted to determine whether $C$. californica mortality was due to hypoxic $\left(<2 \mathrm{mg} \mathrm{O}_{2} \mathrm{l}^{-1}\right)$ conditions, or to a more direct action of bacteria infecting live snails. Snails were collected from a single location in Bolinas Lagoon and set up identically to the previous lab experiment except that no aquarium heaters were used (temperature range 15.5 to $18^{\circ} \mathrm{C}$ ). The snails' exposure to oxygen and bacteria was manipulated in 3 treatments. I maintained all plastic snail boxes with their lips just above the water line to facilitate access to the snails inside. One treatment provided small waterexchange holes in the sides of the snail compartments and bubbled air into each compartment to maintain well-oxygenated water. To this treatment I also added an antibiotic, kanamysin monosulfate $\left(100 \mathrm{mg} \mathrm{l}^{-1}\right)$ to reduce bacteria concentrations. I added $0.5 \mathrm{ml}$ of the antibiotic per snail compartment every $2 \mathrm{~d}$ from April 10 to April 16 and $0.25 \mathrm{ml}$ every 2 to $5 \mathrm{~d}$ from April 19 to May 12. Kanamysin monosulfate is soluble in seawater and affects broad groups of Gram negative and positive bacteria by interfering with bacterial protein synthesis (Sigma manual 1998). To reduce oxygen levels in the other 2 treatments I filled the snail containers with seawater but did not supply water-exchange holes or bubbled air. Of these 2 treatments, one received a dose of antibiotic according to the same schedule as above and the other did not. Thus the 3 treatments represented conditions of (1) high $\mathrm{O}_{2}$, low bacteria, (2) low $\mathrm{O}_{2}$, low bacteria, and (3) low $\mathrm{O}_{2}$, high bacteria. I used 96 snails in each of the first 2 treatments and 102 in the third. During the times antibiotics were added, dead snails were also recorded using the same death criteria as in the previous lab experiment. I measured temperature and oxygen levels every 3 to $7 \mathrm{~d}$ with an ATI Orion \#835 Dissolved Oxygen meter.

To determine the effectiveness of the antibiotic treatment in decreasing and maintaining bacterial levels, halfway through the experiment (April 30) I extracted $3 \mathrm{ml}$ of water from each of 3 replicates of the 2 low-oxygen treatments and preserved it in formalin (10\% final concentration). After inoculation with $33 \mu \mathrm{l}$ of DAPI fluorescent stain, these samples were filtered with a hand vacuum pump onto $0.2 \mu \mathrm{m}$ polycarbonate filters. I made counts of bacteria collected on filters using an epifluorescent microscope with oil immersion at $1000 \times$ (protocol from Porter \& Feig 1980). Differences in bacterial concentrations between the 2 low-oxygen treatments were analyzed using a 1 -tailed $t$-test and confirmed that the application of antibiotics was effective in reducing the amount of bacteria in this treatment. After $30 \mathrm{~d}$ exposure to antibiotics, the concentration of bacteria in the water surrounding the snails in the antibiotic treatments was approximately $50 \%$ that of the untreated water (no antibiotic $\left[ \pm\right.$ SE] $: 1.07 \times 10^{7} \pm$ $1.77 \times 10^{6}$ bacteria cells ml ${ }^{-1}$; antibiotic added: $5.9 \times 10^{6}$ $\pm 2.54 \times 10^{5}$ bacteria cells $\mathrm{ml}^{-1}$; test for equal variances rejected $[F=48.7, \mathrm{df}=2,2, \mathrm{p}<0.04], 1$-tailed $t$-test with unequal variance $[t=2.7, \mathrm{df}=2.1, \mathrm{p}<0.055]$ ).

As Cerithidea californica have been shown to climb readily (Byers 2000b), I quantified attempts by snails to 
emigrate away from stressful conditions on 3 sampling dates during the experiment by recording snails that were climbing the sides of their enclosures. The sampling dates represented the beginning (Day 6), middle (Day 22), and end (Day 34) periods of the $41 \mathrm{~d}$ experimental period. Snails were replaced on the mud bottom of the enclosure after counting. Chi-squared heterogeneity analyses were performed on climbing incidence of live snails in the 2 low-oxygen treatments. Because they demonstrated no significant heterogeneity, these 2 treatments were pooled at each of the 3 sampling dates and compared via chi-squared analysis against climbing rates among live snails in the highoxygen treatment.

The experiment was terminated on May 19, 1999, after snails had been exposed to their treatments a total of $41 \mathrm{~d}$. A final extensive mortality check was made of all snails, as described above, and final oxygen measurements were made. Mortality was analyzed using logistic regression to test for effects of oxygen and antibiotic treatments on snail mortality (SAS catmod procedure).

\section{RESULTS}

\section{Natural experiments}

The submerged marsh panne exhibited a significant drop in live Cerithidea californica density in the sam-

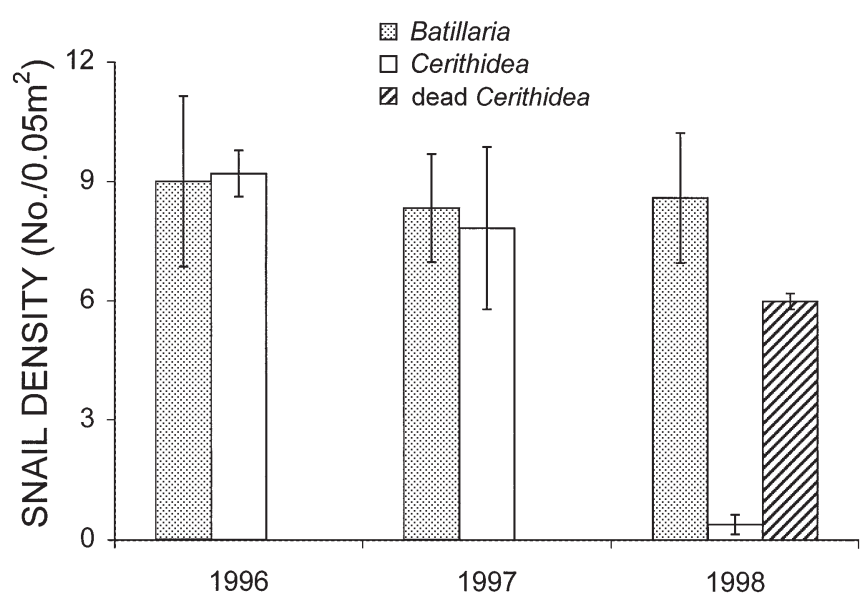

Fig. 1. Batillaria attramentaria, Cerithidea californica. Density of snails $( \pm 1 \mathrm{SE})$ in marsh panne that underwent prolonged submersion prior to 1998 sampling ( $\mathrm{n}=5$ to $6 \mathrm{yr}^{-1}$ ). Live C. Californica populations in 1998 were significantly different from C. californica densities in either of the 2 previous years (Tukey test, 1996 vs 1997, $\mathrm{p}=0.55 ; 1996$ vs 1998, $\mathrm{p}<0.001$; 1997 vs 1998, p < 0.001). None of the B. attramentaria densities through time were significantly different (ANOVA, $F=$ $0.013, \mathrm{p}>0.98$ )

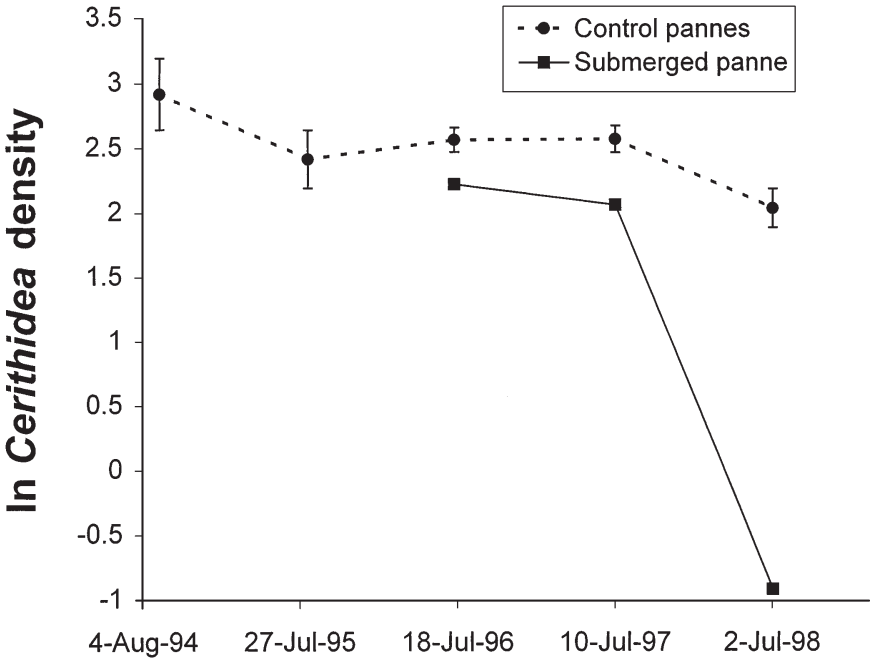

Fig. 2. Changes in the density (ln-transformed) of Cerithidea californica populations in the submerged panne $(\mathrm{n}=5$ to 6 quadrats) and the 4 control marsh pannes $( \pm \mathrm{SE})(\mathrm{n}=6$ to 11 quadrats site ${ }^{-1}$ )

ple year in which submersion occurred (ANOVA, $F=$ 32.3, $\mathrm{df}=2,13, \mathrm{p}<0.001$; Tukey test, 1996 vs 1997, $\mathrm{p}=$ $0.55,1996$ vs $1998, \mathrm{p}<0.001,1997$ vs $1998, \mathrm{p}<0.001$ ) (Fig. 1). Substantial numbers of dead C. californica were present in 1998, while none had been detected in the 2 previous years. Two-thirds of these dead shells (and even 1 of the 2 live C. californica) were stained black and several $(\sim 25 \%)$ had a bacterial film near, and often inside, the aperture. Furthermore, the decline was confined to C. californica, as Batillaria attramentaria numbers remained unaffected and were similar to previous years (ANOVA, $F=0.013, \mathrm{df}=2,13, \mathrm{p}>$ 0.98) (Fig. 1). Only 1 dead $B$. attramentaria was found in all quadrats. None of the other 4 control pannes under the monitoring program were blocked off and submerged, and the change in C. californica density declined only slightly compared to the decline measured in the submerged panne (Fig. 2). The change in C. californica density (i.e., the slope) from 1996 to 1997 was not significantly different between the control pannes and the 'soon-to-be-submerged' panne $(t=$ -0.45 , df $=3, \mathrm{p}=0.68$ ); however, between 1997 and 1998, when the panne became submerged, the change in density was significantly different from the change in density in the control pannes $(t=-4.77, \mathrm{df}=3, \mathrm{p}=$ 0.017) (Fig. 2). B. attramentaria exhibited no significant difference in its trend in density between the control and submerged panne either before submersion $(t=$ 1.02, $\mathrm{df}=3, \mathrm{p}=0.38)$ or after $(t=-0.92, \mathrm{df}=3, \mathrm{p}=0.44)$.

In 1998 in the panne with the dead deer, the densities of Batillaria attramentaria in the 3 sample areas were not significantly different from each other $(F=$ 


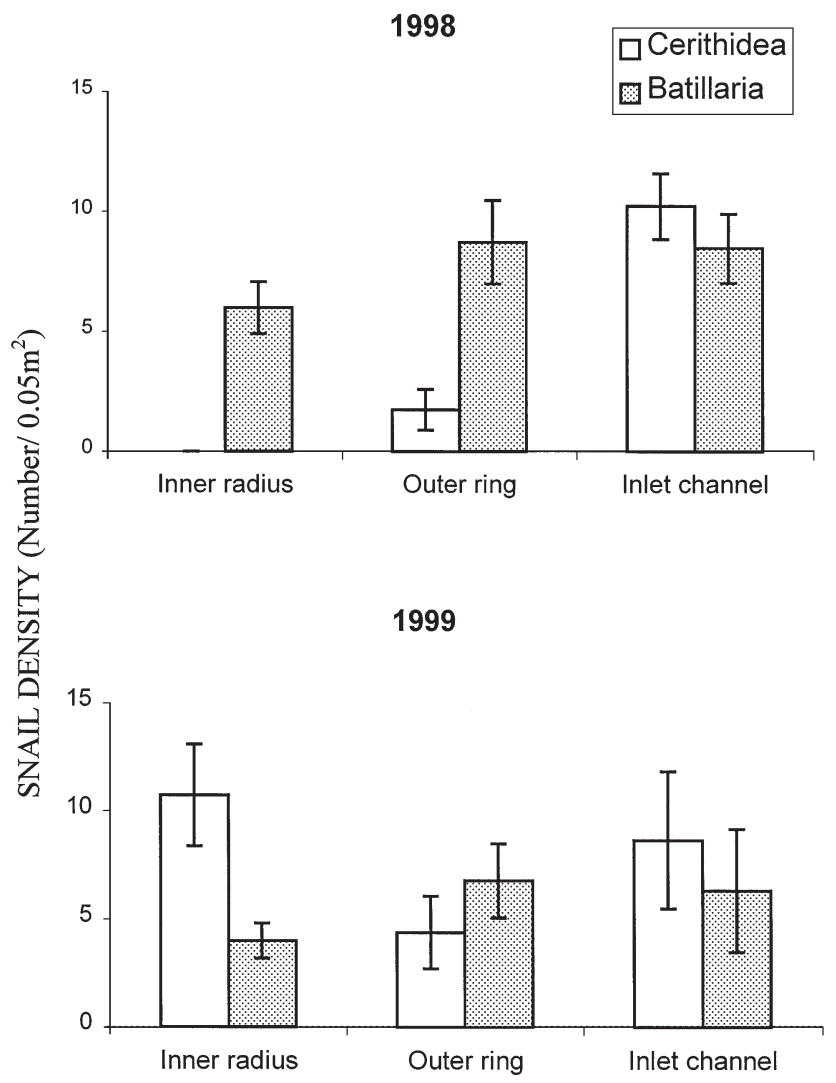

Fig. 3. Batillaria attramentaria, Cerithidea californica. Densities of snails in marsh panne 2 mo after the dead deer was found (1998) (n= 4 quadrats) and 1 yr later (1999) ( $\mathrm{n}=3$ to 5 quadrats). Categories from left to right represent increasing distance from deer. Inner radius was 0 to $0.4 \mathrm{~m}$ from carcass. Only 1 dead C. californica was found in this area in 1998. Outer ring was 0.4 to $1.4 \mathrm{~m}$ from deer. Inlet channel was $>1.5 \mathrm{~m}$ from deer and was also the area of greatest flushing

1.1, df $=2,9, p=0.37$ ). Cerithidea californica density, however, depended significantly on proximity to the deer. The density of $C$. californica in the channel was significantly greater than in the outer ring of the panne $(t=5.25, \mathrm{df}=6, \mathrm{p}<0.002)$. Densities in both areas were substantially higher than the innermost circle around the deer, where no live C. californica were found. (The all-zero values in this area precluded any formal statistical tests.) The inner circle of radius $0.4 \mathrm{~m}$ containing the deer bones and standing water contained only $B$. attramentaria; a few were on the bones themselves (Fig. 3). One dead C. californica was also found in this section. In contrast, in 1999 the densities of each snail species were not significantly different among the three sample areas of the panne (C. californica, $F=2.3$, $\mathrm{df}=2,9, \mathrm{p}>0.15 ; B$. attramentaria, $F=0.73, \mathrm{df}=2,9$, p > 0.5). Furthermore, in 1999 the highest densities of C. californica were found in the inner radius of the panne (Fig. 3). While many bones were still present, the mud surface no longer exhibited any of the colorful bacterial rings or the superficial black, anoxic sediment.

\section{Laboratory experiments}

In the first laboratory experiment, species, collection location, and mortality were significantly non-independent $\left(\chi^{2}=119.7\right.$, df $=7, \mathrm{p}<0.001$, Table 1). Combining data from all collection sites, $34.6 \%$ of Cerithidea californica died due to submersion-related causes while Batillaria attramentaria's mortality rate was only $4.7 \%\left(\chi^{2}=76.1\right.$, $\left.\mathrm{df}=1, \mathrm{p}<0.001\right)$. Also, collection location had a significant effect on $C$. californica's susceptibility to mortality $\left(\chi^{2}=28.3, \mathrm{df}=2, \mathrm{p}<\right.$ 0.001; Table 1). As responses of C. californica collected from pannes 1 and 2 were not significantly different from one another $\left(\chi^{2}=2.02, \mathrm{df}=1, \mathrm{p}>0.15\right)$, the majority of the difference in bacterial susceptibility of snails due to collection location was driven by higher mortality in snails from panne 3 (pannes 1 and 2 pooled vs panne $3, \chi^{2}=24.9$, df $\left.=1, \mathrm{p}<0.001\right)$.

In the second laboratory experiment low and high oxygen concentrations were successfully maintained in their respective treatments (Fig. 4). Only a single Cerithidea californica died in the high-oxygen-level treatment; however, $>27 \%$ of $C$. californica died during $41 \mathrm{~d}$ of exposure to low oxygen (Fig. 5). The difference in C. californica mortality between high- and low-oxygen treatments was highly significant (logistic regression, $\chi^{2}=12.5, \mathrm{df}=1, \mathrm{p}<0.001$ ). Antibiotic addition had little influence on snail mortality (logistic regression $\chi^{2}=0.02$, $\mathrm{df}=1, \mathrm{p}>0.87$ ).

Finally, climbing by snails was much greater in lowoxygen treatments, reaching as high as $60 \%$ (Fig. 6). At all 3 sampling times the difference in climbing between low-oxygen treatments and the high-oxygen treatment was significant (beginning, $\chi^{2}=28.7, \mathrm{df}=1$, $\mathrm{p}<0.001$; middle, $\chi^{2}=63.4, \mathrm{df}=1, \mathrm{p}<0.001$; end, $\chi^{2}=$ 64.7, df $=1, \mathrm{p}<0.001$ ).

Table 1. Results of first laboratory experiment depicting the number of snails of each species collected from 3 locations in the marsh that died as a result of prolonged submersion. Data were analyzed to determine the independence of species, collection location, and mortality

\begin{tabular}{|lcccc|}
\hline \multirow{2}{*}{ Species } & \multicolumn{5}{c|}{ Died/total (percent mortality) } \\
& Panne 1 & Panne 2 & Panne 3 & All pannes \\
\hline Cerithidea & $16 / 84$ & $30 / 103$ & $48 / 85$ & $94 / 272$ \\
Californica & $(19 \%)$ & $(29.1 \%)$ & $(56.5 \%)$ & $(34.6 \%)$ \\
Batillaria & $0 / 84$ & $5 / 104$ & $8 / 89$ & $13 / 277$ \\
attramentaria & $(0 \%)$ & $(4.8 \%)$ & $(9.0 \%)$ & $(4.7 \%)$ \\
\hline
\end{tabular}




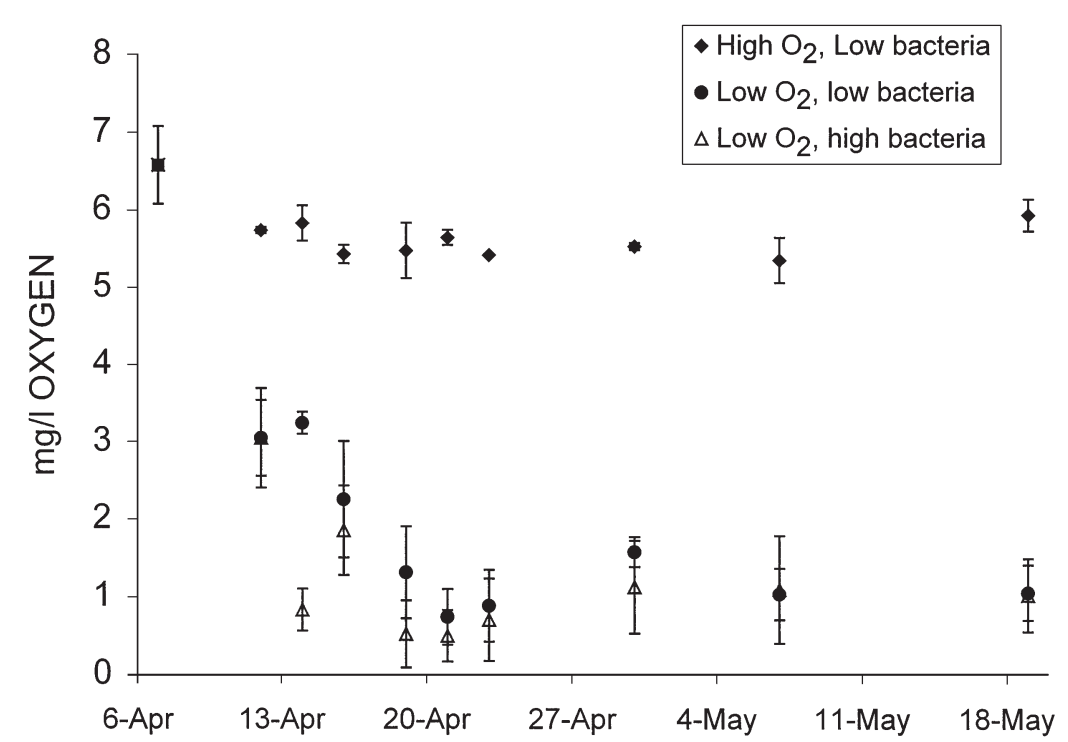

Fig. 4. Dissolved oxygen concentrations $( \pm \mathrm{SE})$ for each treatment throughout second laboratory experiment ( $\mathrm{n}=3$ to 5 samples treatment ${ }^{-1}$ date $^{-1}$ ). Symbol (घ) on first sample date represents average oxygen value across all treatments at experimental set-up

\section{DISCUSSION}

Batillaria attramentaria clearly demonstrates superior resistance to hypoxic conditions compared to its native ecological analog, Cerithidea californica. That the 2 low-bacteria treatments, which differed only in the level of oxygen, produced substantially different C. californica death rates emphasizes the significance of hypoxia (and its associated stresses) as the overriding influence on snail mortality. Sousa \& Gleason (1989) likewise found oxygen to be the most influential factor on C. californica mortality; other abiotic stresses that they examined, including desiccation, high salinity, low salinity, and temperature, had little effect. Bacteria impact the snails in this system indirectly by lowering oxygen levels, which subsequently impact the snail species differentially. This dramatic mortality differential influences $B$. attramentaria's invasion success by further accentuating the advantage it maintains over C. californica in exploitative competition (Byers 2000a).

As the first laboratory experiment indicated, however, snails, particularly Cerithidea californica, collected from different sites within the marsh varied in their susceptibility to hypoxic conditions. This variation could be due to underlying genetic resistance or to bacteria associated with the sediment at a given site (because snails were reared on mud from their collection location). Regardless, this result emphasizes that indirect effects of bacteria may not act universally even over a seemingly small spatial scale ( 100 m).

While the second lab experiment demonstrated hypoxia as the mechanism of microbial impact on Cerithidea californica, finer resolution of the mechanism is possible. Although I controlled for intertreatment differences in temperature and water loss, anaerobic reduction of sulfate by bacteria produces hydrogen sulfide in low-oxygen conditions (Theede et al. 1969, Fenchel \& Riedl 1970, Sousa \& Gleason 1989, Kuever et al. 1996). Exposure of the snails to hydrogen sulfide associated with hypoxic conditions could increase the mortality rate above that induced by low-oxygen levels alone. While not directly quantified, hydrogen sulfide was clearly present in the second lab experiment in the 2 low-oxygen treatments, as evidenced by the black color of sediment in many snail compartments (caused by precipitation of iron sulfide) and a strong 'rotten egg' odor. Also, many of the snails in these treatments had their shells stained black. Thus, under low-oxygen conditions, the effect of low oxygen per se and toxicity poisoning from hydrogen sulfide associated with low-oxygen conditions both could contribute to snail mortality. While hypoxic conditions are ultimately responsible for the observed mortality, further experiments could tease apart the specific mechanism by which these conditions exact their effects.

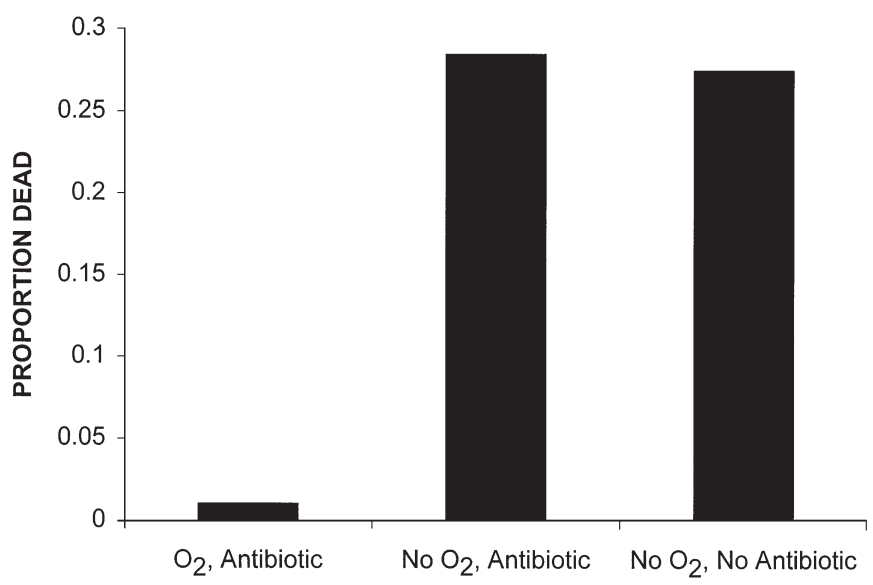

Fig. 5. Proportion of Cerithidea californica that died during $41 \mathrm{~d}$ of exposure in each of 3 laboratory treatments 


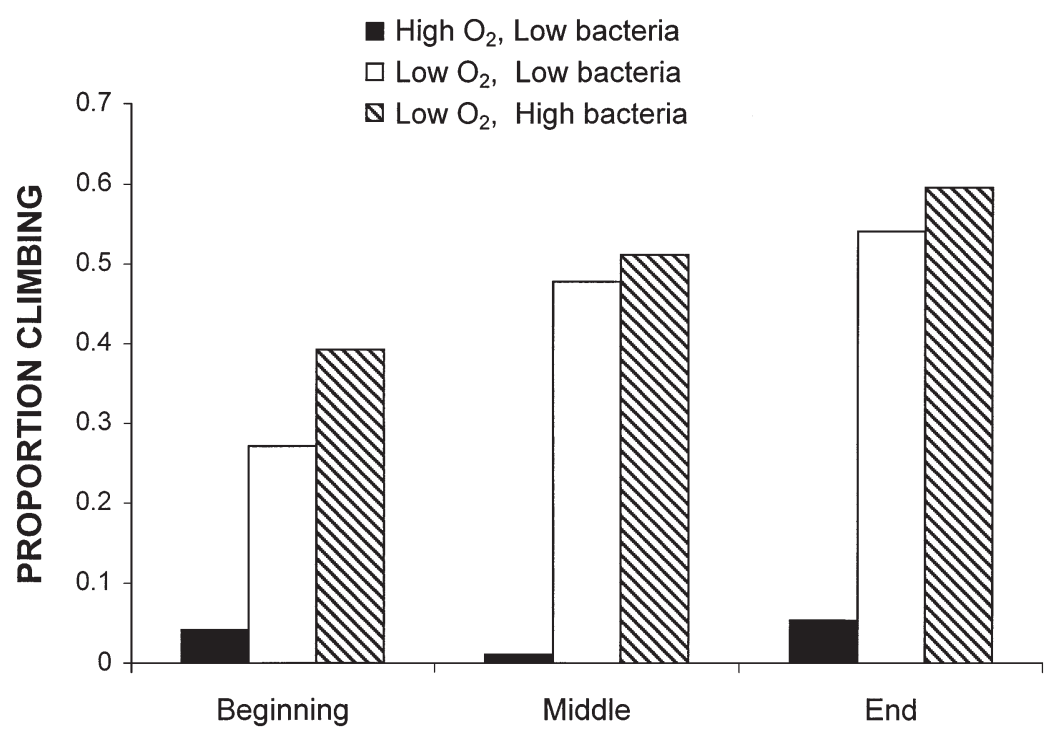

Fig. 6. Proportion of Cerithidea californica climbing the sides of enclosures at the beginning, middle, and end of the second lab experiment. Chi-squared heterogeneity tests indicated that the 2 low-oxygen treatments were homogeneous at all 3 sample times. In all cases climbing in the 2 low-oxygen treatments was significantly higher than in the high-oxygen treatment

In the lab and in the field, Cerithidea californica responded to hypoxic conditions by attempting to emigrate. The spatial scale of the bacterial disturbance, however, appeared to determine C. californica's relative success at escaping. In the panne with the dead deer, where the bacterial infusion was highly localized, C. californica apparently migrated away, as no live $C$. californica and only 1 dead C. californica were found in the area of closest proximity to the rotting carcass. Conversely, in the submerged panne where the bacterial disturbance enveloped the entire panne, almost all C. californica appeared to have died. The sum of live and dead C. californica sampled in this panne after the submersion event nearly matches the total of live snails found in the previous years, suggesting that most of the snails could not locate an avenue of escape from the disturbance and died. Additionally, a faster decline in oxygen may have occurred in the submerged panne than in the anoxic, yet tidally flushed panne with the dead deer, thereby decreasing the ability of Cerithidea to respond with a metabolically taxing response, such as movement.

Cerithidea californica, although relatively more susceptible to death by hypoxia, is still a hardy species that can survive for many days under low-oxygen conditions (see also Sousa \& Gleason 1989) or disperse until conditions improve. For example, in the second laboratory experiment $C$. californica mortality in the low-oxygen treatments was only $9 \%$ after $3 \mathrm{wk}$. Nevertheless, it still succumbs much more quickly than Batillaria attramentaria to long-lasting hypoxia events, and even small relative advantages in B. attramentaria survivorship strongly influence long-term population-level outcomes of $B$. attramentaria over $C$. californica in exploitative competition (Byers \& Goldwasser in press).

The extent of long-lasting hypoxic events probably varies greatly based on the hydrology and biology of a given area; however, patches of hypoxia lasting $\sim 3 \mathrm{wk}$ are not uncommon in Bolinas Lagoon, and are particularly common in summer when drifting algal mats accumulate (Sousa \& Gleason 1989, J.E.B. pers. obs.). Also, Cerithidea californica probably does not need as much time in the field to attain the mortality rates observed in the lab experiments (4 and 6 wk). Specifically, spring and summer water temperatures in Bolinas marsh (up to $38^{\circ} \mathrm{C}$ ) are commonly higher than the temperatures at which my experiments were run (J.E.B. pers. obs.). Such high temperatures often result in higher snail metabolism that may accentuate stress on the snails located in hypoxic conditions (Sousa \& Gleason 1989). Also, these higher temperatures can accelerate decomposition (and thus bacterial consumption of oxygen) of floating mats of Ulva spp. and Enteromorpha spp. common in the summer months (J.E.B. pers. obs.). In general, it may be expected that as eutrophication increasingly plagues many near-shore environments, bacterial outbreaks and their associated anoxic events will increase in spatial extent, frequency and intensity (Officer et al. 1984, Paerl 1985, Seliger et al. 1985, Elmgren 1989, Cooper \& Brush 1991, Parker \& O'Reilly 1991, Dyer \& Orth 1995, Iversen et al. 1998). Even if only a fraction of introduced aquatic species exhibit reduced susceptibility to hypoxia/anoxia, increased anthropogenic nitrogen loading in aquatic environments may have the unexplored consequence of influencing the incidence of successful exotic species invasions.

More generally, dissolved oxygen depletion appears to be one of a growing number of environmental stresses that, in a variety of systems, have been demonstrated to affect the outcome of competition between species (Locke 1996, Takada 1999), alter trophic/community processes (Lafferty \& Kuris 1999, Lenihan et al. 1999), and ultimately create conditions favorable to invasion by exotic species (Ruiz et al. 1999, Simberloff \& Von Holle 1999). Lafferty \& Kuris (1999), for example, demonstrated that multiple stressors can influence the impact of parasites on their hosts. Lenihan et al. (1999) showed that environmental stresses interact to 
determine the level of viral infection in Atlantic oysters. Finally, even non-indigenous species themselves may create stressful conditions that facilitate further invasions by other non-indigenous species (Simberloff \& Von Holle 1999).

In sum, several factors including superior exploitative ability (Byers 2000a) and enhanced resistance to parasitic infection (McDermott 1996) have been shown to create relative advantages for Batillaria attramentaria over Cerithidea californica and foster its successful invasion of California salt marshes. The present study demonstrates that differential impact by microbial activity is yet another advantage that aids $B$. attramentaria's establishment and displacement of its native competitor. Due to the ubiquity of bacteria and anthropogenic enhancement of their activity, reduced susceptibility to bacteria and their modification of surrounding environmental conditions may be an increasingly influential factor in the outcome of biological invasions.

Acknowledgements. I thank T. Byers, A. Hsu, R. Hudson, J. Meyer, and J. and C. O'Connor for their help with lab and fieldwork. Thanks to R. Bolser, S. Gaines, B. Murdoch, E. Noonburg, C. Peterson, R. Strathmann, and 3 anonymous reviewers for comments and suggestions on earlier versions of this manuscript. This work was funded by a SeaGrant/ National Fish and Wildlife Graduate Research Grant for nonindigenous species and by the Sanctuaries and Reserves Division, Office of Ocean and Coastal Resource Management, National Ocean Service, National Oceanic and Atmospheric Administration (Awd \#: NA870R0269).

\section{LITERATURE CITED}

Barber BJ, Mann R (1994) Growth and mortality of eastern oysters, Crassostrea virginica (Gmelin, 1791) and Pacific oysters, Crassostrea gigas (Thunberg, 1793) under challenge from the parasite, Perkinsus marinus. J Shellfish Res 13(1):109-114

Barrett EM (1963) The California oyster industry. Fish Bull 123:2-103

Bonnot P (1935) The California oyster industry. Calif Fish Game 21(1):65-80

Breitburg DL (1990) Near-shore hypoxia in the Chesapeake Bay-patterns and relationships among physical factors. Estuar Coast Shelf Sci 30(6):593-609

Byers JE (1999) The distribution of an introduced mollusc and its role in the long-term demise of a native confamilial species. Biol Invasions 1(4):339-353

Byers JE (2000a) Competition between two estuarine snails: implications for invasions of exotic species. Ecology 81(5): $1225-1239$

Byers JE (2000b) Effects of body size and resource availability on dispersal in a native and a non-native estuarine snail. J Exp Mar Biol Ecol 248(2):133-150

Byers JE, Goldwasser L (in press) Exposing the mechanism and timing of impact of non-indigenous species on native species. Ecology

Carlton JT (1975) Extinct and endangered populations of the endemic mudsnail Cerithidea californica in Northern California. Bull Am Malacol Union, p 65-66

Carlton JT (1992) Introduced marine and estuarine mollusks of North America: an end-of-the-20th-century perspective. J Shellfish Res 11(2):489-505

Carlton JT, Geller JB (1993) Ecological roulette: the global transport of nonindigenous marine organisms. Science 261:78-82

Chu FLE (1996) Laboratory investigations of susceptibility infectivity, and transmission of Perkinsus marinus in oysters. J Shellfish Res 15(1):57-66

Cohen AN, Carlton JT (1998) Accelerating invasion rate in a highly invaded estuary. Science 279:555-558

Cooper SR, Brush GS (1991) Long-term history of Chesapeake Bay anoxia. Science 254:992-996

Crawley MJ (1987) What makes a community invasible? In: Gray AJ, Crawley MJ, Edwards PJ (eds) Colonization, succession, and stability. Blackwell Scientific, Oxford, p 429-453

Das TS, Stickle WB (1993) Sensitivity of crabs Callinectes sapidus and $C$. similis and the gastropod Stramonita haemastoma to hypoxia and anoxia. Mar Ecol Prog Ser 98: 263-274

Drake JA, Mooney HA, di Castri F, Groves RH, Kruger FJ, Rejmanek M, Williamson M (1989) Ecology of biological invasions: a global perspective. John Wiley and Sons New York

Dyer KR, Orth RJ (1995) Changes in fluxes in estuaries: implications from science and management. Olsen and Olsen Fredensborg

Elmgren R (1989) Man's impact on the ecosystem of the Baltic Sea: energy flows today and at the turn of the century. Ambio 18:326-332

Fenchel TM, Riedl RJ (1970) The sulfide system: a new biotic community underneath the oxidized layer of marine sand bottoms. Mar Biol 7:255-268

Freeland WJ (1983) Parasites and the coexistence of animal host species. Am Nat 121:223-236

Gunnlaugsdottir B, Gudmundsdottir BK (1997) Pathogenicity of atypical Aeromonas salmonicida in Atlantic salmon compared with protease production. J Appl Microbiol 83(5):542-551

Hanley KA, Vollmer DM, Case TJ (1995) The distribution and prevalence of helminths, coccidia and blood parasites in two competing species of gecko: implications for apparent competition. Oecologia 102:220-229

Hochberg ME (1991) Population dynamic consequences of the interplay between parasitism and intraspecific competition for host-parasite systems. Oikos 61:297-306

Huffaker CB (1971) The phenomenon of predation and its roles in nature. In: den Boer PJ, Gradwell GR (eds) Dynamics of populations: proceedings of the Advanced Study Institute on dynamics of numbers in populations, Oosterbeck, The Netherlands, 7-18 Sept 1970. Center for Agricultural Publications and Documentation, Wageningen, p 327-343

Iversen TM, Grant R, Nielson K (1998) Nitrogen enrichment of European inland and marine waters with special attention to Danish policy measures. Environ Pollut 102 (Suppl 1):771-780

Kuever J, Wawer C, Lillebaek R (1996) Microbiological observations in the anoxic basin Golfo Dulce, Costa Rica. Rev Biol Trop 44(Suppl 3):49-57

Lafferty KD (1993) Effects of parasitic castration on growth, reproduction and population dynamics of the marine snail Cerithidea californica. Mar Ecol Prog Ser 96:229-237

Lafferty KD, Kuris AM (1996) Biological control of marine pests. Ecology 77(7):1989-2000 
Lafferty KD, Kuris AM (1999) How environmental stress affects the impacts of parasites. Limnol Oceanogr 44(3, Part 2):925-931

Landsberg JH (1995) Tropical reef-fish disease outbreaks and mass mortalities in Florida, USA: what is the role of dietary biological toxins? Dis Aquat Org 22(2):83-100

Lawton JH, Brown KC (1986) The population and community ecology of invading insects. Philos Trans R Soc Lond Biol Sci 314:607-617

Lenihan HS, Peterson CH (1998) How habitat degradation through fishery disturbance enhances impacts of hypoxia on oyster reefs. Ecol Appl 8(1):128-140

Lenihan HS, Micheli F, Shelton SW, Peterson CH (1999) The influence of multiple stressors on susceptibility to parasites: an experimental determination with oysters. Limnol Oceanogr 44(3, Part 2):910-924

Locke A (1996) Applications of the Menge-Sutherland model to acid-stressed lake communities. Ecol Appl 6(3):797-805

Lodge DM (1993) Biological invasions: lessons for ecology. Trends Ecol Evol 8(4):133-137

Marcus NM, Lutz RV (1994) Effects of anoxia on the viability of subitaneous eggs of planktonic copepods. Mar Biol 121(1):83-87

McDermott S (1996) Parasites, density, and disturbance: factors influencing coexistence of Cerithidea californica and Batillaria attramentaria. Moss Landing Marine Lab, Moss Landing, CA

Mills EL, Leach JH, Carlton JT, Secor CL (1993) Exotic species in the Great Lakes: a history of biotic crises and anthropogenic introductions. J Great Lakes Res 19(1):1-54

Minchella DJ, Scott ME (1991) Parasitism: a cryptic determinant of animal community structure. Trends Ecol Evol 6: $250-254$

Officer CB, Biggs RB, Taft J, Cronin LE, Tyler MA, Boynton WR (1984) Chesapeake Bay anoxia: origin, development, and significance. Science 223:22-27

Paerl H (1985) Enhancement of marine primary production by nitrogen-enriched acid rain. Nature 315:747-749

Park T (1948) Experimental studies of interspecific competition. I. Competition between populations of flour beetles Tribolium confusum Duval and T. castaneum Herbst. Ecol Monogr 18:265-307

Parker CA, O'Reilly JE (1991) Oxygen depletion in Long Island Sound: a historical perspective. Estuaries 14: 248-264

Porter KG, Feig S (1980) The use of DAPI for identifying and counting aquatic microflora. Limnol Oceanogr 25:943-948

Porter KG, Saunders PA, Haberyan KA, Macubbin AE, Jacobsen TR, Hodson RE (1996) Annual cycle of autotrophic and heterotrophic production in a small, monomictic Piedmont lake (Lake Oglethorpe): analog for the effects of climatic warming on dimictic lakes. Limnol Oceanogr 41(5): 1041-1051

Price PW, Westoby M, Rice B, Atsatt PR, Fritz RS, Thompson JN, Mobley K (1986) Parasite mediation in ecological interactions. Annu Rev Ecol Syst 17:487-505

Price PW, Westoby M, Rice B (1988) Parasite-mediated competition: some predictions and tests. Am Nat 131:544-555

Editorial responsibility: Charles Peterson (Contributing Editor), Morehead City, North Carolina, USA
Ruiz GM, Fofonoff P, Hines AH, Grosholz ED (1999) Nonindigenous species as stressors in estuarine and marine communities: assessing invasion impacts and interactions. Limnol Oceanogr 44(3, Part 2):950-972

Schall JJ (1992) Parasite-mediated competition in Anolis lizards. Oecologia 92:58-64

Seliger HH, Boggs JA, Biggley WH (1985) Catastrophic anoxia in the Chesapeake Bay in 1984. Science 228:70-73

Settle WH, Wilson LT (1990) Invasion by the variegated leafhopper and biotic interactions: parasitism, competition, and apparent competition. Ecology 71(4):1461-1470

Sigma manual (1998) Biochemicals and reagents for life science research. Sigma Corporation, St Louis, MO

Sikorowski PP, Lawrence AM (1994) Microbial contamination and insect rearing. Am Entomol 40(4):240-253

Simberloff D, Von Holle B (1999) Positive interactions of nonindigenous species: invasional meltdown? Biol Invasions $1(1): 21-32$

Sokal RR, Rohlf FJ (1995) Biometry. WH Freeman and Company, New York

Sousa WP (1983) Host life history and the effect of parasitic castration on growth: a field study of Cerithidea californica (Gastropoda: Prosobranchia) and its trematode parasites. J Exp Mar Biol Ecol 73:273-296

Sousa WP, Gleason M (1989) Does parasitic infection compromise host survival under extreme environmental conditions? The case for Cerithidea californica (Gastropoda: Posobranchia). Oecologia 80:456-464

Takada Y (1999) Influence of shade and number of boulder layers on mobile organisms on a warm temperate boulder shore. Mar Ecol Prog Ser 189:171-179

Theede H, Ponat A, Hiroki K, Schlieper C (1969) Studies on the resistance of marine bottom invertebrates to oxygendeficiency and hydrogen sulfide. Mar Biol 2:325-337

Trowbridge CD (1995) Establishment of the green algae, Cudium fragile spp. tomentosoides, on New Zealand rocky shores: current distribution and invertebrate grazers. J Ecol 83:949-965

Uncles RJ, Joint I, Stephens JA (1998) Transport and retention of suspended particulate matter and bacteria in the Humber-Ouse Estuary, United Kingdom, and their relationship to hypoxia and anoxia. Estuaries 21(4A):597-612

Vistisen B, Vismann B (1997) Tolerance to low oxygen and sulfide in Amphiura filiformis and Ophiura albida (Echinodermata: Ophiuroidea). Mar Biol 128(2):241-246

Wells JD, Henderson G (1993) Fire ant predation on native and introduced subterranean termites in the laboratory: effect of high soldier number in Coptotermes formosanus. Ecol Entomol 18:270-274

Whitlatch RB (1974) Studies on the population ecology of the salt marsh gastropod Batillaria zonalis. Veliger 17:47-55

Wilson CG (1989) Post-dispersal seed predation of an exotic weed, Mimosa pigra L., in the Northern Territory. Aust J Ecol 14:235-240

Yamada SB, Sankurathri CS (1977) Direct development in the intertidal gastropod Batillaria zonalis. Veliger 20:179

Zar JH (1996) Biostatistical analysis. Prentice Hall, Upper Saddle River, NJ

Submitted: August 24, 1999; Accepted: May 4, 2000

Proofs received from author(s): August 21, 2000 